\title{
Mass transfer and reaction kinetics of sulfuryl fluoride absorption with aqueous sodium hydroxide solutions*
}

\author{
Yong NIE ${ }^{\dagger 1}$, Xiao-jiang LIANG ${ }^{1}$, Mei-zhen $\mathrm{LU}^{1}$, Feng-wen $\mathrm{YU}^{1}$, Da-yong $\mathrm{GU}^{2}$, Min MIN ${ }^{3}$, Jian-bing JI \\ ( ${ }^{l}$ College of Chemical Engineering, Zhejiang University of Technology, Hangzhou 310014, China) \\ ( ${ }^{2}$ Shenzhen International Travel Health Care Center, Shenzhen 518033, China) \\ $\left({ }^{3}\right.$ Center for Biorefining and Department of Bioproducts and Biosystems Engineering, University of Minnesota, Saint Paul, MN 55108, USA) \\ †E-mail: ny_zjut@zjut.edu.cn \\ Received Feb. 23, 2014; Revision accepted May 8, 2014; Crosschecked June 24, 2014
}

\begin{abstract}
The mass transfer and reaction kinetics of sulfuryl fluoride $\left(\mathrm{SO}_{2} \mathrm{~F}_{2}\right)$ absorption with aqueous sodium hydroxide $(\mathrm{NaOH})$ solutions were studied in an experimental double-stirred cell. Results showed that $\mathrm{SO}_{2} \mathrm{~F}_{2}$ absorption with $\mathrm{NaOH}$ was followed by a reaction model employing a fast pseudo-first-order. The second-order rate constant for $\mathrm{SO}_{2} \mathrm{~F}_{2}$ absorption with aqueous $\mathrm{NaOH}$ solutions was determined to be $1.44 \mathrm{~m}^{3} /(\mathrm{mol} \cdot \mathrm{s})$ at $298 \mathrm{~K}$. Three models were used in this chemical absorption process, and in each case, the same expression of enhancement factor was obtained. A comparison was made between the experimental enhancement factor and the value calculated from the model, and the maximum relative deviation was less than $4.2 \%$. The proposed model expression gave a reasonable fit with the experimental values, indicating that mass transfer correlations are valid for scaling up design.
\end{abstract}

Key words: Sulfuryl fluoride, Sodium hydroxide, Mass transfer, Reaction kinetics, Absorption, Double-stirred cell doi: 10.1631 jzus.A1400055

Document code: A

CLC number: X701

\section{Introduction}

Sulfuryl fluoride $\left(\mathrm{SO}_{2} \mathrm{~F}_{2}\right)$ was commercially introduced as a fumigant beginning in 1961 (Tsai, 2010). As a gaseous fumigant, $\mathrm{SO}_{2} \mathrm{~F}_{2}$ has been widely used for pest control in buildings, construction materials, and agricultural related products, such as soil, timber, and food (Derrick et al., 1990; Athanassiou et al., 2012; Chayaprasert et al., 2012; Cao et al., 2014), owing to its strong dispersivity in different materials and nearly no residues left after treatment (Meikle and Stewart, 1962).

With the wide application of $\mathrm{SO}_{2} \mathrm{~F}_{2}$ in fumiga-

\footnotetext{
* Project supported by the National Natural Science Foundation of China (No. 51107118), and the Science and Technology Plan of General Administration of Quality Supervision of China (No. 201010256651.9)

(C) Zhejiang University and Springer-Verlag Berlin Heidelberg 2014
}

tion, its greenhouse effect and toxicity were gradually recognized and became the focus of attention. $\mathrm{SO}_{2} \mathrm{~F}_{2}$ is a strong greenhouse gas with global warming potential of 4780 (relative to $\mathrm{CO}_{2}$ for the 100 year time horizon), and the concentration of $\mathrm{SO}_{2} \mathrm{~F}_{2}$ in the global atmosphere has been increasing $5 \%$ each year since 1978 (Papadimitriou et al., 2008; Mühle et al., 2009). In addition, $\mathrm{SO}_{2} \mathrm{~F}_{2}$ gas was marked as an inhalation hazardous material, and long term exposure can cause damage to a human's central nervous system and inhalation system, etc. (Tsai, 2010). However, $\mathrm{SO}_{2} \mathrm{~F}_{2}$, after fumigation, is released directly into the atmosphere at present. Therefore, it is increasingly important to find a reasonable way to remove $\mathrm{SO}_{2} \mathrm{~F}_{2}$ effectively after fumigation.

To achieve this result, our research group previously developed a two-step method based on dielectric barrier discharge (DBD) plasma followed with a chemical absorption, in which the results showed 
that $\mathrm{SO}_{2} \mathrm{~F}_{2}$ could be removed efficiently using this two-step method (Nie et al., 2013a); however, high energy consumption of the DBD plasma process limits its future industrial applications.

Recently, a new approach of using chemical absorption alone for the removal of $\mathrm{SO}_{2} \mathrm{~F}_{2}$ has been developed (Nie et al., 2013b). $\mathrm{SO}_{2} \mathrm{~F}_{2}$ is nearly insoluble in water in neutral conditions; however, $\mathrm{SO}_{2} \mathrm{~F}_{2}$ can be rapidly hydrolyzed in aqueous alkaline media due to the fact that nucleophilic hydroxyl ions will attack the $\mathrm{S}$ atom and replace one of the $\mathrm{F}$ ions (Cady and Misra, 1974). Therefore, using aqueous $\mathrm{NaOH}$ solution as the absorbent could enhance the absorption rates of $\mathrm{SO}_{2} \mathrm{~F}_{2}$ in comparison with using only water.

The present work involves an investigation of mass transfer and reaction kinetics in the absorption of gaseous $\mathrm{SO}_{2} \mathrm{~F}_{2}$ with aqueous $\mathrm{NaOH}$ solution in an experimental double-stirred cell, including a zone of mass transfer and reaction kinetics, enhancement factor, etc. The results can provide the theory base for the industrial design of a chemical absorber to remove $\mathrm{SO}_{2} \mathrm{~F}_{2}$ after fumigation.

\section{Materials and methods}

\subsection{Materials}

Sulfuryl fluoride (99.9\%) in a cylinder was obtained from the Hangzhou Maoyu Electronic Chemicals Co., Ltd., China. Air in a cylinder was obtained from the Hangzhou Jingong Specialty Gases Co., Ltd., China. Sodium hydroxide (96\%) and potassium biphthalate $(99.9 \%)$ were obtained from the $\mathrm{Si}$ nopharm Chemical Reagent Co., Ltd., China.

\subsection{Apparatus and procedure}

The experimental setup is illustrated in Fig. 1, in which the $\mathrm{SO}_{2} \mathrm{~F}_{2}$ absorption was conducted in an experimental double-stirred cell. The detailed description of the double-stirred cell used for the absorption measurements is available elsewhere (Shi and Zhong, 2005; Zhang et al., 2007). The cell has a water jacket through which water from a constant temperature bath is circulated to maintain the desired temperature of $298 \mathrm{~K}$. The stirred cell is a glass cylinder with an $8.0 \mathrm{~cm}$ inner diameter and a length of $15.5 \mathrm{~cm}$, which is equipped with four vertical baffles and two stirring blades. The stirring blades are driven by a separate DC motor in the gas and liquid phases.

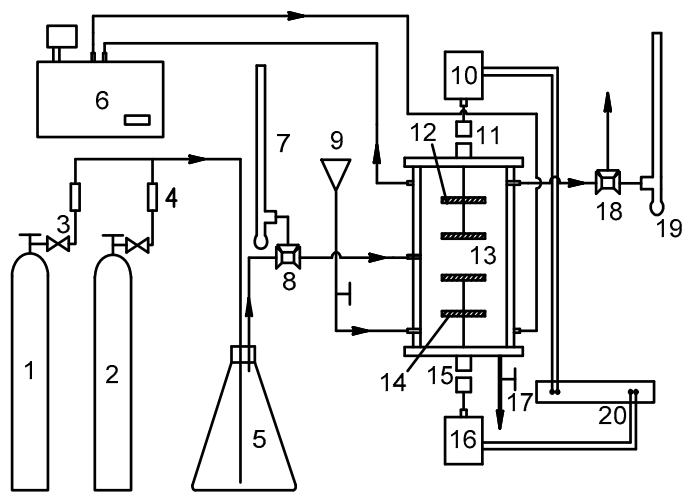

Fig. 1 Experimental apparatus for $\mathrm{SO}_{2} \mathrm{~F}_{2}$ absorption in an experimental double-stirred cell

1: $\mathrm{SO}_{2} \mathrm{~F}_{2} ; 2$ : air cylinder; 3: gas control valve; 4: flow meter; 5: buffer; 6 : water bath; 7, 19: soap-film meter; 8 , 18: three-way cock; 9: entrance of liquid; 10, 16: DC motor; 11, 15: magnetic force gearing; 12, 14: stirring blade; 13: absorber; 17: liquid control valve; 20: stirrerspeed controller

A mixture of $\mathrm{SO}_{2} \mathrm{~F}_{2}$ and air with a $\mathrm{SO}_{2} \mathrm{~F}_{2}$ concentration ranging from $0.2 \%$ to $0.5 \%$ in volume was fed into the stirred cell at a fixed gas flow rate of $100 \mathrm{ml} / \mathrm{min}$. Gaseous $\mathrm{SO}_{2} \mathrm{~F}_{2}$ was absorbed by the aqueous $\mathrm{NaOH}$ solution in the cell. The $\mathrm{NaOH}$ solution was prepared by adding the solid $\mathrm{NaOH}$ to distilled water to obtain the desired $\mathrm{NaOH}$ concentration, calibrating with a potassium biphthalate solution. Most of the experiments were performed with an aqueous $\mathrm{NaOH}$ solution volume $V_{\mathrm{L}}$ of $200 \mathrm{ml}$.

The inlet and outlet gas concentrations of $\mathrm{SO}_{2} \mathrm{~F}_{2}$ for the cell were analyzed by a gas chromatography (GC) equipped with a Gaspro plot column and a flame photometric detector (7890A, Agilent Technologies, USA). The sensitivity of the GC for $\mathrm{SO}_{2} \mathrm{~F}_{2}$ analysis was $5 \times 10^{-7}$ in volume. The experimental absorption rate $N_{\mathrm{A}}$ can be calculated from

$$
N_{\mathrm{A}}=G\left(C_{\text {Gin }}-C_{\text {Gout }}\right) / A \text {, }
$$

where $C_{\text {Gin }}$ and $C_{\text {Gout }}$ are the inlet and outlet gas concentrations of the cell, respectively; $A$ is the effective interfacial area of the cell, which is influenced slightly by the stirring with a constant gas-liquid interface of $0.00264 \mathrm{~m}^{2}$; and $G$ is the total gas flow rate. 
All of the experiments for $\mathrm{SO}_{2} \mathrm{~F}_{2}$ absorption were carried out at atmospheric pressure.

\subsection{Physical properties of the $\mathrm{NaOH}-\mathrm{SO}_{2} \mathrm{~F}_{2}$ system}

The liquid and gas phase diffusivities of $\mathrm{SO}_{2} \mathrm{~F}_{2}$ can be predicated from the model developed by Wilke and Chang (1955) and Wilke and Lee (1955), respectively. The solubility of $\mathrm{SO}_{2} \mathrm{~F}_{2}$ in the water $(H)$ can be calculated (Derrick et al., 1990; Tsai, 2010). In addition, the liquid phase diffusivity of $\mathrm{NaOH}$ is obtained from Tan et al. (1990). Some of the parameters for the $\mathrm{NaOH}-\mathrm{SO}_{2} \mathrm{~F}_{2}$ system are listed as follows: the temperature is $298 \mathrm{~K}$; the molecular diffusivity for $\mathrm{SO}_{2} \mathrm{~F}_{2}$ in the air and water $\left(D_{\mathrm{SO}_{2} \mathrm{~F}_{2} \text {-air }}\right.$ and $\left.D_{\mathrm{SO}_{2} \mathrm{~F}_{2} \text {-water }}\right)$ are $1.24 \times 10^{-5} \mathrm{~m}^{2} / \mathrm{s}$ and $1.19 \times 10^{-9} \mathrm{~m}^{2} / \mathrm{s}$, respectively; the molecular diffusivity for $\mathrm{NaOH}$ in the water $\left(D_{\text {NaOH-water }}\right)$ is $3.09 \times 10^{-9} \mathrm{~m}^{2} / \mathrm{s}$; and $H$ is $7.27 \times 10^{-5} \mathrm{~mol} /(\mathrm{L} \cdot \mathrm{kPa})$.

\subsection{Mass transfer coefficients}

The gas-side and liquid-side mass transfer coefficients in the cell, $k_{\mathrm{GA}}$ and $k_{\mathrm{LA}}^{0}$ (where the superscript 0 represents without chemical reaction and the subscript A represents $\mathrm{SO}_{2} \mathrm{~F}_{2}$ ), are calculated from the empirical correlations of Shi et al. (1996) as follows:

$$
\begin{aligned}
& k_{\mathrm{LCO}_{2}}^{0}=1.635 \times 10^{-6} n_{\mathrm{L}}^{0.56}, \\
& k_{\mathrm{GSO}_{2}}=5.878 \times 10^{-8} n_{\mathrm{G}}^{0.70}, \\
& k_{\mathrm{LA}^{0}}^{0}=k_{\mathrm{LCO}_{2}}^{0}\left(D_{\mathrm{A}} / D_{\mathrm{CO}_{2}}\right)^{2 / 3}, \\
& k_{\mathrm{GA}_{\mathrm{A}}}=k_{\mathrm{GSO}_{2}}\left(D_{\mathrm{A}} / D_{\mathrm{SO}_{2}}\right)^{2 / 3},
\end{aligned}
$$

where $k_{\mathrm{LCO}_{2}}^{0}$ is the liquid-side mass transfer coefficient for carbon dioxide $\left(\mathrm{CO}_{2}\right)$ without chemical reaction at $298 \mathrm{~K}, k_{\mathrm{GSO}_{2}}$ is the gas-side mass transfer coefficient for sulfur dioxide $\left(\mathrm{SO}_{2}\right)$ at $298 \mathrm{~K}, n_{\mathrm{L}}$ is the liquid phase stirrer speed, $n_{\mathrm{G}}$ is the gas phase stirrer speed, $D_{\mathrm{A}}, D_{\mathrm{CO}_{2}}$, and $D_{\mathrm{SO}_{2}}$ are the molecular diffusivities for $\mathrm{SO}_{2} \mathrm{~F}_{2}, \mathrm{CO}_{2}$, and $\mathrm{SO}_{2}$, respectively.

In this study, the value of $k_{\mathrm{GA}}$ for $\mathrm{SO}_{2} \mathrm{~F}_{2}$ is $3.157 \times 10^{-6} \mathrm{kmol} /\left(\mathrm{m}^{2} \cdot \mathrm{s} \cdot \mathrm{kPa}\right)$ at $300 \mathrm{r} / \mathrm{min}$ and $298 \mathrm{~K}$, and $k_{\mathrm{LA}}^{0}$ is $1.918 \times 10^{-5} \mathrm{~m} / \mathrm{s}$ at $150 \mathrm{r} / \mathrm{min}$ and $298 \mathrm{~K}$.

\subsection{Interfacial concentration of $\mathrm{SO}_{2} \mathrm{~F}_{2}$ in liquid phase}

The interfacial concentration of $\mathrm{SO}_{2} \mathrm{~F}_{2}$ in the liquid phase $C_{\mathrm{Ai}}$ is a key factor affecting the reaction kinetics for the absorption of $\mathrm{SO}_{2} \mathrm{~F}_{2}$ in the liquid phase. At a low $\mathrm{SO}_{2} \mathrm{~F}_{2}$ concentration, $C_{\mathrm{Ai}}$ can be estimated using Henry's law. In the experimental double-stirred cell, the complete mixing coefficients for the gas and liquid phases were all close to 1 with a liquid stirring speed of $150 \mathrm{r} / \mathrm{min}$ and a gas stirring speed of $300 \mathrm{r} / \mathrm{min}$ (Gu, 1986). Thus, the partial pressure $P_{\mathrm{A} 0}$ (where the subscript 0 represents without chemical reaction) of the bulk gas stream at the outlet of the cell was used to calculate the interfacial concentration of $\mathrm{SO}_{2} \mathrm{~F}_{2}$ as follows:

$$
C_{\mathrm{Ai}}=H\left(P_{\mathrm{A} 0}-N_{\mathrm{A}} / k_{\mathrm{GA}}\right) .
$$

\subsection{Absorption process of $\mathrm{SO}_{2} \mathrm{~F}_{2}$ into the aqueous $\mathrm{NaOH}$ solution}

The absorption process of $\mathrm{SO}_{2} \mathrm{~F}_{2}$ into the aqueous $\mathrm{NaOH}$ solution consists of the following two steps:

$$
\begin{aligned}
& \mathrm{SO}_{2} \mathrm{~F}_{2} \text { (gas) } \leftrightarrow \mathrm{SO}_{2} \mathrm{~F}_{2} \text { (aqueous), } \\
& \mathrm{SO}_{2} \mathrm{~F}_{2} \text { (aqueous) }+\mathrm{NaOH}(\text { aqueous }) \rightarrow \\
& \quad \mathrm{HOSO}_{2} \mathrm{~F} \text { (aqueous) }+\mathrm{NaF} \text { (aqueous). }
\end{aligned}
$$

\section{Results and discussion}

\subsection{Determination of the mass transfer and the reaction kinetics zone}

To study the chemical absorption process, the zone of the mass transfer and reaction kinetics should be determined firstly. Generally, the kinetics zones are classified based on the magnitude of the reaction rate, and kinetics zones are mainly used to indicate the influences of the chemical reaction on the process of gas-liquid mass transfer and reaction. Table 1 shows how to determine the kinetics zone, according to the effect of factors influencing absorption and reaction on each kinetics zone using the film theory (Tan et al., 1990). 
Table 1 Factors influencing the gas-liquid absorption and reaction

\begin{tabular}{|c|c|c|c|c|c|c|c|c|}
\hline \multirow{2}{*}{ Parameter instruction } & \multicolumn{8}{|c|}{ Zone of mass transfer and reaction kinetics } \\
\hline & A & $\mathrm{B}$ & $\mathrm{C}$ & $\mathrm{D}$ & $\mathrm{E}$ & $\mathrm{F}$ & G & $\mathrm{H}$ \\
\hline Concentration of reactant $\mathrm{NaOH}$ in bulk of liquid, $C_{\mathrm{BL}}$ & + & - & + & + & $?$ & $?$ & + & + \\
\hline Intensity of pressure of $\mathrm{SO}_{2} \mathrm{~F}_{2}$ in bulk of gas, $P$ & + & + & + & + & $?$ & $?$ & + & + \\
\hline Interfacial areas, $A$ & + & + & + & + & + & + & + & - \\
\hline Liquid volume, $V_{\mathrm{L}}$ & - & - & - & - & + & + & + & + \\
\hline Liquid-side mass-transfer coefficient, $k_{\mathrm{L}}$ & + & - & + & - & $?$ & $?$ & + & - \\
\hline Gas-side mass-transfer coefficient, $k_{\mathrm{G}}$ & + & + & + & + & $?$ & $?$ & + & - \\
\hline Second-order rate constant, $k_{2}$ & - & - & + & + & $?$ & $?$ & + & + \\
\hline
\end{tabular}

A: instantaneous reaction; B: instantaneous reaction in diffusion film; C: fast reaction; D: fast pseudo- $m$ th-order reaction; E: moderately fast reaction; F: moderately fast pseudo-mth-order reaction; G: slow reaction in bulk liquid; H: very slow reaction in bulk liquid; '+': effected by factor; '-': not effected by factor; '?': may be effected by factor, but the rate equation will not be changed

Based on the above method, the zone determining experiments for the absorption of $\mathrm{SO}_{2} \mathrm{~F}_{2}$ into aqueous $\mathrm{NaOH}$ solutions were designed as shown in Table 2. The basic conditions of the experiments are as follows: $T=298 \mathrm{~K}, P_{\text {in }}=0.5 \mathrm{kPa}$ (the inlet partial pressure of $\mathrm{SO}_{2} \mathrm{~F}_{2}$, equivalent to a regular $\mathrm{SO}_{2} \mathrm{~F}_{2}$ application rate of $20 \mathrm{~g} / \mathrm{m}^{3}$ used in container fumigation), $n_{\mathrm{G}}=300 \mathrm{r} / \mathrm{min}, n_{\mathrm{L}}=150 \mathrm{r} / \mathrm{min}, V_{\mathrm{L}}=200 \mathrm{ml}$, and $C_{\mathrm{BL}}=47.8 \mathrm{mmol} / \mathrm{L}$ (bulk concentration, where the subscript $\mathrm{B}$ represents $\mathrm{NaOH}$ ). In our testing, the bulk concentration $C_{\mathrm{BL}}$ of $\mathrm{NaOH}$ was much higher than the interfacial concentration of $\mathrm{SO}_{2} \mathrm{~F}_{2}$ in the liquid phase $C_{\mathrm{Ai}}$. Thus, the bulk concentration of $\mathrm{NaOH}$ was considered to be a constant during the absorption process of $\mathrm{SO}_{2} \mathrm{~F}_{2}$.

Table 2 Determination of zone of mass transfer and reaction kinetics

\begin{tabular}{cc}
\hline Parameter & $\begin{array}{c}\text { Absorption rate } \\
\left(\times 10^{-5} \mathrm{~mol} /\left(\mathrm{m}^{2} \cdot \mathrm{s}\right)\right)\end{array}$ \\
\hline$V_{\mathrm{L}}=150 \mathrm{ml}$ & 1.04 \\
$V_{\mathrm{L}}=200 \mathrm{ml}$ & 1.08 \\
\hline$n_{\mathrm{L}}=150 \mathrm{r} / \mathrm{min}$ & 1.08 \\
$n_{\mathrm{L}}=100 \mathrm{r} / \mathrm{min}$ & 1.05 \\
\hline$C_{\mathrm{BL}}=47.8 \mathrm{mmol} / \mathrm{L}$ & 1.08 \\
$C_{\mathrm{BL}}=57.4 \mathrm{mmol} / \mathrm{L}$ & 1.25 \\
$C_{\mathrm{BL}}=66.9 \mathrm{mmol} / \mathrm{L}$ & 1.36 \\
\hline
\end{tabular}

As can be seen from Table 2, firstly, the variation of liquid volume $V_{\mathrm{L}}$ has a slight effect on the absorption rate of $\mathrm{SO}_{2} \mathrm{~F}_{2}$, according to Table 1, the zones of $\mathrm{E}$ to $\mathrm{H}$ can be excluded. Secondly, the liquid-side mass transfer coefficient can be changed by changing the liquid stirring speed, the variation of liquid stirring speed $n_{\mathrm{L}}$ has an insignificant effect on the absorption rate of $\mathrm{SO}_{2} \mathrm{~F}_{2}$ (Table 2); therefore, the zones of $\mathrm{A}$ and $\mathrm{C}$ in Table 1 can be excluded. Thirdly, the variation of concentration of the reactant $\mathrm{NaOH}$ in bulk of liquid $C_{\mathrm{BL}}$ has a great effect on the absorption rate of $\mathrm{SO}_{2} \mathrm{~F}_{2}$, according to Table 1 ; therefore, the zone of $\mathrm{B}$ can be excluded. Thus, the kinetics zone for the absorption of gaseous $\mathrm{SO}_{2} \mathrm{~F}_{2}$ with $\mathrm{NaOH}$ solution belongs to $\mathrm{D}$, a fast pseudo- $m$ th-order reaction.

\subsection{Determination of fast pseudo-first-order re- action and second-order rate constant $k_{2}$}

Based on the Dankwerts theory (Dankwerts, 1970), the absorption rate for a fast pseudo- $m$ th-order reaction is given by

$$
N_{\mathrm{A}}=\sqrt{2 k_{m+1} D_{\mathrm{A}} C_{\mathrm{Ai}}^{m+1} C_{\mathrm{BL}} /(m+1)},
$$

where $m$ is the reaction order.

A plot of $N_{\mathrm{A}}$ versus $C_{\mathrm{Ai}}$ can give the reaction order $m$ for $\mathrm{SO}_{2} \mathrm{~F}_{2}$. Fig. 2 shows the effect of the bulk concentration of $\mathrm{NaOH}$ on the $\mathrm{SO}_{2} \mathrm{~F}_{2}$ absorption rate as a function of the interfacial concentration of $\mathrm{SO}_{2} \mathrm{~F}_{2}$ in the liquid phase. There was a linear relationship between the $\mathrm{SO}_{2} \mathrm{~F}_{2}$ absorption rate $N_{\mathrm{A}}$ and the interfacial concentration of $\mathrm{SO}_{2} \mathrm{~F}_{2}$ in the liquid phase $C_{\mathrm{Ai}}$. Thus, the results confirmed that the hydrolysis reaction for $\mathrm{SO}_{2} \mathrm{~F}_{2}$ was a fast pseudo-first-order reaction $(m=1)$. In addition, as illustrated in Fig. 2, the $\mathrm{SO}_{2} \mathrm{~F}_{2}$ absorption rate $N_{\mathrm{A}}$ had a positive relationship with both $C_{\mathrm{Ai}}$ and $C_{\mathrm{BL}}$.

To determine the forward second-order rate constant $k_{2}$ for the hydrolysis reaction of $\mathrm{SO}_{2} \mathrm{~F}_{2}$, the 
mass transfer model described in Eq. (9) was used. The values for the second-order rate constant can be derived from Fig. 2, and the average value of the rate constant $k_{2}$ calculated at $298 \mathrm{~K}$ was $1.44 \mathrm{~m}^{3} /(\mathrm{mol} \cdot \mathrm{s})$. Cady and Misra (1974) found that the rate constant $k_{2}$ for the hydrolysis reaction of $\mathrm{SO}_{2} \mathrm{~F}_{2}$ was $0.418 \mathrm{~m}^{3} /(\mathrm{mol} \cdot \mathrm{s})$, which is smaller than that in this study. The possible reason for this phenomenon is the difference of the measuring method. In our case, the overall dynamic processes of $\mathrm{SO}_{2} \mathrm{~F}_{2}$ absorption and the subsequent hydrolysis reaction were taken into account. However, in the experiments of Cady and Misra (1974), the process of $\mathrm{SO}_{2} \mathrm{~F}_{2}$ absorption was not considered, and the hydrolysis reaction of $\mathrm{SO}_{2} \mathrm{~F}_{2}$ was restricted in the liquid solution, in which $\mathrm{SO}_{2} \mathrm{~F}_{2}$ was dissolved in advance; therefore, maybe some of the $\mathrm{SO}_{2} \mathrm{~F}_{2}$ evaporated from the solution during the hydrolysis reaction, and resulted in the deviation for the determination of the forward second-order rate constant $k_{2}$.

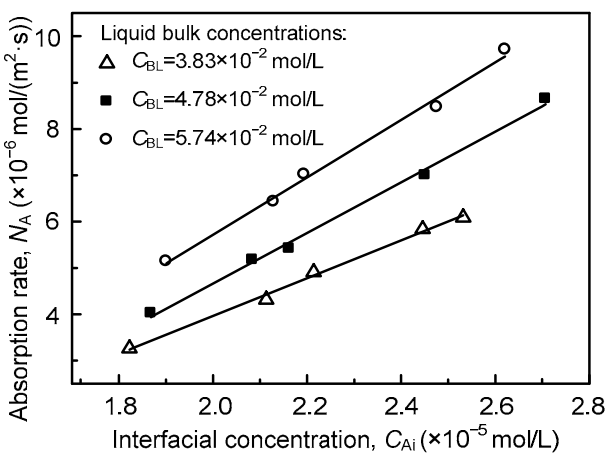

Fig. 2 Effect of the bulk concentration of $\mathrm{NaOH}$ on the $\mathrm{SO}_{2} \mathrm{~F}_{2}$ absorption rate as a function of the interfacial concentration of $\mathrm{SO}_{2} \mathrm{~F}_{2}$ in the liquid phase

\subsection{Enhancement factor $E$}

The enhancement factor $E$ determines the mass transfer rate for a chemical absorption process, which is very important for the industrial absorber design. In this section, the comparison between the experimental value and the model value for the enhancement factor is conducted.

Generally, the experimental value of the enhancement factor for a fast reaction can be obtained by

$$
N_{\mathrm{A}}=E k_{\mathrm{LA}}^{0} C_{\mathrm{Ai}},
$$

where $N_{\mathrm{A}}, k_{\mathrm{LA}}^{0}$, and $C_{\mathrm{Ai}}$ are experimental values, as shown in Fig. 3. The experimental value of the enhancement factor increases with the increase of the bulk concentration $C_{\mathrm{BL}}$ of $\mathrm{NaOH}$.

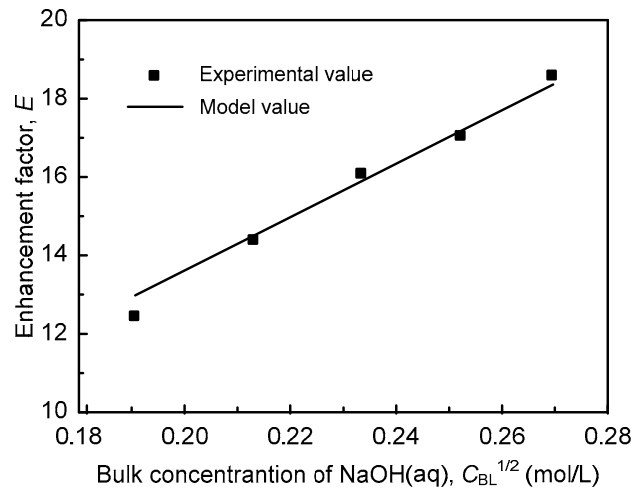

Fig. 3 Comparison of experimental and model values for the enhancement factor

For the aim of modeling the enhancement factor of a fast pseudo-first-order reaction, three widely used mass transfer models based on the film, penetration, and surface renewal theories, respectively, are applied to predict the enhancement factor here as follows (Tan et al., 1990):

Film theory model: $E=H a / \tanh H a$,

Penetration theory model: $E=H a+\pi /(8 H a)$,

Surface renewal theory model: $E=\sqrt{1+H a^{2}}$,

where $H a$ is the dimensionless Hatta number, defined as follows:

$$
H a=\sqrt{k_{2} D_{\mathrm{A}} /\left(k_{\mathrm{LA}}^{0}\right)^{2} C_{\mathrm{BL}}^{1 / 2}} .
$$

In terms of the above three models, when $H a>3$, the mathematical expression of the enhancement factor could be the same equation as follows (Dankwerts, 1970):

$$
E=H a=\sqrt{k_{2} D_{\mathrm{A}} /\left(k_{\mathrm{LA}}^{0}\right)^{2} C_{\mathrm{BL}}^{1 / 2}}
$$

According to the above experimental value of the enhancement factor, Eq. (15) could be used as the model expression of the enhancement factor, and the 
corresponding mathematical expression in this study is

$$
E=68.08 C_{\mathrm{BL}}^{1 / 2}
$$

The corresponding model values are also shown in Fig. 3. The proposed model expression based on the three mass transfer models gives a reasonable fit with the experimental values: the average relative deviation is $1.7 \%$, and the maximum relative deviation is $4.2 \%$.

\subsection{Validation of the fast pseudo-first-order reaction}

For a bimolecular-second-order reaction, the universal non-steady-state model for the enhancement factor can be expressed by (Tan et al., 1990)

$$
E=\frac{H a \sqrt{1-(E-1) /(r S)}}{\tanh [H a \sqrt{1-(E-1) /(r S)}]},
$$

where $r$ represents the ratio of the diffusion coefficients in the liquid phase, and $S$ represents the ratio of the stoichiometric concentrations in the liquid phase. These two dimensionless parameters are given by

$$
\begin{gathered}
r=D_{\mathrm{B}} / D_{\mathrm{A}}, \\
S=C_{\mathrm{BL}} /\left(b C_{\mathrm{Ai}}\right), \quad b=1,
\end{gathered}
$$

where $D_{\mathrm{B}}$ is the molecular diffusivity for $\mathrm{NaOH}$, and $b$ is the stoichiometric number.

In terms of a second-order reaction, the condition to be regarded as a pseudo-first-order reaction is that: $r^{1 / 2} S / H a \geq 10$. Table 3 shows the calculating results based on the experimental data depicted in Fig. 3, and the experiments were performed with $P_{\text {in }}$ of $0.36 \mathrm{kPa}$ for the inlet gas stream (equivalent to a $\mathrm{SO}_{2} \mathrm{~F}_{2}$ application rate of $14.4 \mathrm{~g} / \mathrm{m}^{3}$ ).

Table 3 Validation of fast pseudo-first-order reaction

\begin{tabular}{ccccc}
\hline$C_{\mathrm{BL}}(\mathrm{mol} / \mathrm{L})$ & $C_{\mathrm{Ai}}(\mathrm{mol} / \mathrm{L})$ & $S$ & $H a$ & $r^{1 / 2} S / H a$ \\
\hline $3.89 \times 10^{-2}$ & $2.470 \times 10^{-5}$ & 1575 & 13.4 & 189 \\
$4.94 \times 10^{-2}$ & $2.370 \times 10^{-5}$ & 2084 & 15.1 & 222 \\
$5.74 \times 10^{-2}$ & $2.363 \times 10^{-5}$ & 2429 & 16.3 & 240 \\
$7.03 \times 10^{-2}$ & $2.347 \times 10^{-5}$ & 2995 & 18.1 & 267 \\
$7.64 \times 10^{-2}$ & $2.330 \times 10^{-5}$ & 3279 & 18.8 & 281 \\
\hline
\end{tabular}

As can be seen from Table 3, the condition of $r^{1 / 2} S / H a \geq 10$ is satisfied for our test cases. Hence, the results confirmed that the absorption of $\mathrm{SO}_{2} \mathrm{~F}_{2}$ into aqueous $\mathrm{NaOH}$ solutions is a fast pseudo-first-order reaction.

\section{Conclusions}

The mass transfer and reaction kinetics of the absorption of $\mathrm{SO}_{2} \mathrm{~F}_{2}$ with aqueous $\mathrm{NaOH}$ solutions were studied in an experimental double-stirred cell. Conclusions can be drawn as follows.

1. $\mathrm{SO}_{2} \mathrm{~F}_{2}$ absorption with $\mathrm{NaOH}$ was a fast pseudo-first-order reaction. The second-order rate constant was determined from experimental results and found to be $1.44 \mathrm{~m}^{3} /(\mathrm{mol} \cdot \mathrm{s})$ at $298 \mathrm{~K}$.

2. Three widely used mass transfer models based on the film, penetration, and surface renewal theories, respectively, were applied in this mass transfer with a chemical reaction process, and the same expression of enhancement factors was obtained. A comparison was made between the experimental enhancement factor and the data calculated from the models, and the maximum relative deviation was less than $4.2 \%$.

Associated with the developed model for the enhancement factor $E$, mass transfer coefficients, and material balance in the scrubber, the number of the theoretical plate in the scrubber could be calculated accurately, which is the critical index used to determine the performance and effectiveness of the scrubber. Furthermore, the scaling up study for the removal of $\mathrm{SO}_{2} \mathrm{~F}_{2}$ in a rotating zigzag high gravity bed could be carried out to set up mobile equipment.

\section{References}

Athanassiou, C.G., Phillips, T.W., Aikins, M.J., et al., 2012. Effectiveness of sulfuryl fluoride for control of different life stages of stored-product psocids (Psocoptera). Journal of Economic Entomology, 105(1):282-287. [doi:10.1603/EC11209]

Cady, G.H., Misra, S., 1974. Hydrolysis of sulfuryl fluoride. Inorganic Chemistry, 13(4):837-841. [doi:10.1021/ic50 134a016]

Cao, A., Guo, M., Yan, D., et al., 2014. Evaluation of sulfuryl fluoride as a soil fumigant in China. Pest Management Science, 70(2):219-227. [doi:10.1002/ps.3535]

Chayaprasert, W., Maier, D.E., Subramanyam, B., et al., 2012. Gas leakage and distribution characteristics of methyl bromide and sulfuryl fluoride during fumigations in a pilot flour mill. Journal of Stored Products Research, 50(1):1-7. [doi:10.1016/j.jspr.2012.03.002] 
Dankwerts, P.V., 1970. Gas-liquid Reactions. McGraw-Hill, New York, p.110-118.

Derrick, M.R., Burgess, H.D., Baker, M.T., et al., 1990. Sulfuryl fluoride (Vikane): A review of its use as a fumigant. Journal of the American Institute for Conservation, 29(1):77-90. [doi:10.1179/019713690806 046082]

Gu, Y.X., 1986. The Chemical Absorption Process in the Disposal of Nitric Oxide. MS Thesis, Zhejiang University, Hangzhou (in Chinese).

Meikle, R.W., Stewart, D., 1962. Structural fumigants, the residue potential of sulfuryl fluoride, methyl bromide, and methanesulfonyl fluoride in structural fumigations. Journal of Agricultural and Food Chemistry, 10(5): 393-397. [doi:10.1021/jf60123a011]

Mühle, J., Huang, J., Weiss, R.F., et al., 2009. Sulfuryl fluoride in the global atmosphere. Journal of Geophysical Research: Atmospheres, 114(D5):D05306. [doi:10.1029/ 2008JD011162]

Nie, Y., Zheng, Q., Liang, X., et al., 2013a. Decomposition treatment of $\mathrm{SO}_{2} \mathrm{~F}_{2}$ using packed bed $\mathrm{DBD}$ plasma followed by chemical absorption. Environmental Science \& Technology, 47(14):7934-7939. [doi:10.1021/es400 786p]

Nie, Y., Ji, J., Liang, X., et al., 2013b. An appratus for removing sulfuryl fluoride based on chemical absorption. China Patent 201320395223.3 (in Chinese).

Papadimitriou, V.C., Portmann, R.W., Fahey, D.W., et al., 2008. Experimental and theoretical study of the atmospheric chemistry and global warming potential of
$\mathrm{SO}_{2} \mathrm{~F}_{2}$. Journal of Physical Chemistry A, 112(49): 12657-12666. [doi:10.1021/jp806368u]

Shi, Y., Zhong, Z., 2005. A rigorous model for absorption of carbon dioxide into aqueous $\mathrm{N}$-methyldiethanolamine solution. Chemical Engineering Communications, 192(9):1180-1193. [doi:10.1080/00986440590473353]

Shi, Y., Littlejohn, D., Chang, S.G., 1996. Kinetics of NO absorption in aqueous iron (II) bis (2, 3-dimercapto1-propanesulfonate) solutions using a stirred reactor. Industrial \& Engineering Chemistry Research, 35(5): 1668-1672. [doi:10.1021/ie950655m]

Tan, T.N., Jin, Y.Z., Luo, Y.S., 1990. The Process of Mass Transfer and Reaction. Zhejiang University Press, Hangzhou, China, p.3-92 (in Chinese).

Tsai, W.T., 2010. Environmental and health risks of sulfuryl fluoride, a fumigant replacement for methyl bromide. Journal of Environmental Science and Health, Part C, 28(2):125-145. [doi:10.1080/10590501.2010.481806]

Wilke, C.R., Chang, P., 1955. Correlation of diffusion coefficients in dilute solutions. AIChE Journal, 1(2): 264-270. [doi:10.1002/aic.690010222]

Wilke, C.R., Lee, C.Y., 1955. Estimation of diffusion coefficients for gases and vapors. Industrial \& Engineering Chemistry, 47(6):1253-1257. [doi:10.1021/ ie50546a056]

Zhang, P., Shi, Y., Wei, J.W., 2007. Kinetics region and model for mass transfer in carbon dioxide absorption into aqueous solution of 2-amino-2-methyl-1-propanol. Separation and Purification Technology, 56(3):340-347. [doi:10.1016/j.seppur.2007.02.010]

\section{中文概要:}

\section{本文题目: 氢氧化钠溶液吸收硫酰氟的传质反应动力学}

Mass transfer and reaction kinetics of sulfuryl fluoride absorption with aqueous sodium hydroxide solutions

研究目的: 确定氢氧化钠溶液化学吸收硫酰氟的传质反应动力学区域, 建立增强因子模型。

研究方法: 研究气液传质测定设备双搅拌釜中氢氧化钠溶液化学吸收硫酰氟的过程, 并结合实验研究与 理论分析建立了增强因子模型。

重要结论: 基于氢氧化钠溶液化学吸收硫酰氟过程的实验研究, 确定了氢氧化钠溶液化学吸收硫酰氟的 传质反应动力学区域为快速拟一级反应。得到了 $298 \mathrm{~K}$ 下其二级反应速率常数为 $1.44 \mathrm{~m}^{3} /(\mathrm{mol} \cdot \mathrm{s})$, 并建立了增强因子模型 $E=68.08 C_{\mathrm{BL}}{ }^{1 / 2}$, 为脱除熏蒸后残留硫酰氟的工业化应 用提供了理论依据。

关键词组: 硫酰氟; 氢氧化钠; 传质; 反应动力学; 化学吸收; 双摚拌釜 